\title{
Crop water budgeting for rainfed cotton for crop planning and management in Coimbatore
}

\author{
M.LALITHA $^{1^{*}}$, S.MANI ${ }^{2}$ and R. SIVASAMY ${ }^{2}$ \\ ${ }^{1}$ National Bureau of Soil Survey and Land Use Planning, Bangalore-560 024. \\ ${ }^{2}$ Tamil Nadu Agricultural University, Coimbatore - 641003. \\ *Corresponding author: mslalit@yahoo.co.in
}

\begin{abstract}
Analysis of water balance components was carried out for cotton crop in Annur block of Coimbatore district $\left(11^{\circ} 14^{\prime}\right.$ to $11^{\circ} 23^{\prime} \mathrm{N}$ latitude and $77^{\circ} 08^{\prime}$ to $77^{\circ} 13^{\prime} \mathrm{E}$ longitude)based on the soil information (1:50, 000 scale) and thirty years (1975-2005) climatic data.Soil moisture availability index showed that $37^{\text {th }}$ standard week was found to be highly suitable for taking up cotton sowing due to assured rainfall. The water requirement satisfaction index indicated that about 87 per cent of the crop water requirement is satisfied by the soil moisture in the control section irrespective of soil type. The crop will facemoisture deficit from $4^{\text {th }}$ to $8^{\text {th }}$ standard weeks which coincide with harvesting stage.
\end{abstract}

Keywords : Crop water balance,soil moisture availability index, water budget,crop water requirement index

The sustainability of agricultural system at present is threatened by water and nutrient related constraints. Crop water management in rainfed region is crucial factor in determining crop yield since the region solely depends on rainfall having limited access to irrigation. Rainfall being highly variable resources, it becomes imperative to synchronize the crop growth period with soil moisture availability period (Shine, 2008). In view of the further water supplies for irrigation become constrained, it is imperative to enhance of water use in the field by better utilization of available water (Schaible and Aillery, 2012). This can be achieved through assessment of water balance components in the field, to minimize the unproductive water losses (Singh, 2005).The water balance method of determining water deficiency is a tool which indicates the time when moisture is needed and how much to irrigate (Thakuraletal., 2009)by taking into account of all the inflows and outflows from a hydrologic system (Hillel, 1982). Richardson and Ritchie (1973) developed a soil water balance model based on ET requirement to predict plant water requirement. Many researchers have developed water balance model to estimate the water availability to the crop by using rainfall, reference crop evapotranspiration, water holding capacity (Frere and Popov, 1979) and crop coefficients (Kc) (Wright, 1982). The water requirement satisfaction index developed by Allen $e t$ al.,(1998)is an operational monitoring index indicates the performance of a crop based on the availability of water during growing season. It is determined as the ratio of seasonal actual crop evapotranspiration (AET) to the crop water requirement (WR) (Senay et al.,2011).The water requirement satisfaction index (WRSI) estimated in the field and yield data were significantly correlated(Gabriel Senayand James Verdin, 2002) for sorghum crop. The WRSI model was particularly successful in capturing the response of the crop during a relatively dry year and it was possible to infer the magnitude of yield variability by water than the other factor. Having this in mind the present investigation was undertaken to evaluate the water balance components based on soil and climatic properties for cotton crop in rainfed situation of Annur block of Coimbatore.

\section{MATERIALS AND METHODS}

\section{Study area}

The study area was Annur block of Coimabtore district located at $11^{\circ} 14^{\prime}$ to $11^{\circ} 23^{\prime} \mathrm{N}$ latitude and $77^{\circ} 08^{\prime}$ to $77^{\circ} 13^{\prime} \mathrm{E}$ longitude. The major soil type of the study area is red and black soils and the climate is sub tropical. The elevation of the study area is $338 \mathrm{~m}$ above mean sea level. The area receives mean annual rainfall of $850 \mathrm{~mm}$ and bulk of the rain is received during South West Monsoon (SWM). The mean maximum and minimum temperature are $30.5^{\circ} \mathrm{C}$ and $18.6^{\circ} \mathrm{C}$, respectively. The analysis of 30 years rainfall data revealed that the soil moisture control section was moist for 135 consecutive days in a year. Hence, the soil moisture regime was classified as Ustic. The soil temperature regime was assessed as isohyperthermic by computing the soil temperature from the air temperature (Soil Survey Staff, 
2010). Since the area mostly depends on rainfall for cultivation, rainfed cotton and sorghum are the major crops being cultivated.

\section{Soil analysis}

The soil survey was carried out at 1:50,000 scale and soil samples were collected from the seven representative pedons for laboratory analysis. The soil samples were analyzed for various physical and chemical properties following standard procedures (Jackson, 1967). The particle size distribution was done by international pipette method (Piper, 1966), bulk density by core samplermethod (Gupta and Dakshinamurthi, 1980) and water holding capacity by the method given by Richards, (1934). The soils of the study area were classified based on the morphological, physical, chemical and exchangeable properties and climatic data (soil moisture and temperature regimes) following the Keys to Soil Taxonomy (Soil Survey Staff, 2010).

\section{Crop water budgeting}

The daily maximum and minimum temperature, relative humidity, rainfall, wind velocity and solar radiation for the period of thirty years (1975-2005) were collected from the record of agro climatic research centre, Coimbatore and the total weekly rainfall and PET were computed. The moisture availability index (MAI) was calculated using 50 per cent probability rainfall as per the Sarkar and Biswas (1988) method. The weekly moisture availability index was calculated using the following formula.

$\mathrm{MAI}=\mathrm{PD} / \mathrm{PET} ; \quad$ Where

PD - Dependable precipitation; PET - Potential evapotranspiraton

A simple weekly crop water balance was used to calculate water surplus and deficit at various stages of crop growth (Frere and Popov, 1979). The average weekly PET values were calculated using the Penman Monteith method and the available soil moisture was calculated by using the following formula

$$
\mathrm{ASM}_{(\mathrm{w})}=\mathrm{ASM}_{(\mathrm{w}-1)}+\mathrm{ER}_{(\mathrm{w})}-\text { Crop ET } \mathrm{ET}_{(\mathrm{w})} \quad \text { Where, }
$$

$\mathrm{ASM}=$ Available soil moisture $(\mathrm{mm}) ; \mathrm{ER}=$ Effective rainfall $(\mathrm{mm}) ; \mathrm{W}=$ Running index of the week

The soil moisture availability period for individual soils of the study area was computed for control section and $1 \mathrm{~m}$ depth following the procedure of Sehgal and Mandal (1993). The water requirement satisfaction index (WRSI) was determined as the running total of the weekly water deficits that are expressed as a percentage of the total crop water requirement (TWR) for the entire season

$$
\mathrm{WRS} 1=\mathrm{WRSI}_{(\mathrm{w}-1)}+\left(\mathrm{ASM}_{(\mathrm{w})} / \mathrm{TWR}\right) \times 100
$$

The WRSI is initially 100 per cent and remains at this value until thereis water deficit, when it is decreased by the percentage deficit as a fraction of the seasonal water requirement.

\section{RESULT AND DISCUSSION}

\section{Soil properties}

The distribution of clay content varied widely between the soils. The soils of Vadakkalur,Allapalayam and Kuppipalayam showed an increasing trend of clay percentage with depth which can be indirectly observed in soil texture (Table 1). The soils of Ambodi and Odderpalayam exhibited a decreasing trend initially to certain depth and increased thereafter (unimodal distribution). The other soils exhibited decreasing trend of clay distribution with depth function (Leelavathi et al., 2009). The Kariampalayam series has got very deep soil $(<150 \mathrm{~cm})$ followed by deep soil (100-150 cm depth) in Allapalayam series, moderately deep $(75-100 \mathrm{~cm})$ soils in Ambodi, Vadakkalur and Odderpalayam series. The soils of Kuppipalayam and Annur Mettupalayam series were found moderately shallow $(50-75 \mathrm{~cm})$ soil depth. The lowest bulk density of $1.24 \mathrm{Mg} \mathrm{m}^{-3}$ was recorded in Vadakkalur soil and the highest was noticed in Kariampalayam soil $\left(1.49 \mathrm{Mg} \mathrm{m}^{-3}\right)$. The bulk density in all soils was increased with depth. The low bulk density of surface horizons was associated with cultural operation and addition of crop residue and high BD in subsurface was due to filling up of pores by elluvial materials leading to compaction (Dhale and Jagdish Prasad, 2009). The available water holding capacity varied from 7.5 per cent to 15.6 per cent and it was increased with depth. The lowest found in the soils has sandyloam texture which is poor water holding capacity and highest was found in clay soils. Same wise available water content is concern, though Kariampalayam series has got very deep soil, because of its lightsoil texture, the available water content was low compared to Vadakkalur soil which was found high due to its heavy texture despite of its depth. The variation of available water content of the soil was due to the influence of texture, silt, clay content and type of clay (Verma et al., 2008).

\section{Soil moisture availability period}

The soil moisture availability to extent the length of growing period (LGP) for individual soils of study area was computed using available soil moisture present in the soil 
moisture control section (SMCS) and $1 \mathrm{~m}$ soil depth (Table 1). The soil moist days for the soil moisture control section were in the range between 140 to 150 days and for the $1 \mathrm{~m}$ depth were between 150 to 170 days. Among the series studied, Kariampalyam soil was having high number soil moist days was particularly due to its very deep soil $(>150 \mathrm{~cm}$ depth) and less soil moisture loss from deeper layers intern results high volumetric water content (204 mm). The soil moist days in $1 \mathrm{~m}$ depth resulted high values (166 days) in Vadakkalur and Allapalayam soil series because of its high clay content $(>35 \%)$ and ultimately the volumetric water content also were high ( $156 \mathrm{~mm}$ and $175 \mathrm{~mm}$, respectively). Hence the soil moisture control section is greatly affected by soil texture and depth of soil (Yamoahet al., 1998). The number of soil moist days in soils was more upto $1 \mathrm{~m}$ depth than the soil moisture control section due to the greater retention of moisture in the deeper layers. The same time cotton crop has the ability to extract water from layers of soil below the main root zone to sustain the water stress under drought condition (Jordan and Ritchie, 1971). So the crop in heavy textured soil will be sustained because of high volumetric content and soil moist days compared to light textured soil which needs supplementary irrigation in the later stages of the cotton crop to meet out high evaporative demand and crop water requirement.

\section{Moisture availability index (MAI)}

The growing period of cotton starts from $37^{\text {th }}$ standard week and terminatesin $8^{\text {th }}$ standard week. Continuous MAI of $>0.33$ was observed only for a short period from $37^{\text {th }}$ to $49^{\text {th }}$ standard weeks (Fig. 1). The water balance study showed that since there was less than $5 \mathrm{~mm}$ rainfall from 13 weeks after sowing, the deficit was observed in the last 11 weeks. As it falls on the harvesting stage, there was less possibility for the reduction in the yield due to water stress. Crop establishment is the crucial stage in any crop which happens in short span of time during which we should avoid crop stress. Hence the sowing has to be taken up in right time so that crop establishment has to be finished during the period of continuous MAI. The analysis also revealed that the short and medium duration crops may be selected for the successful crop production in the study area thereby the water stress induced yield loss can be avoided.

\section{Water budget for cotton}

The results of water balance analysis describing various components like maximum available water holding capacity, surplus/deficit weeks, cumulative surplus/deficit 


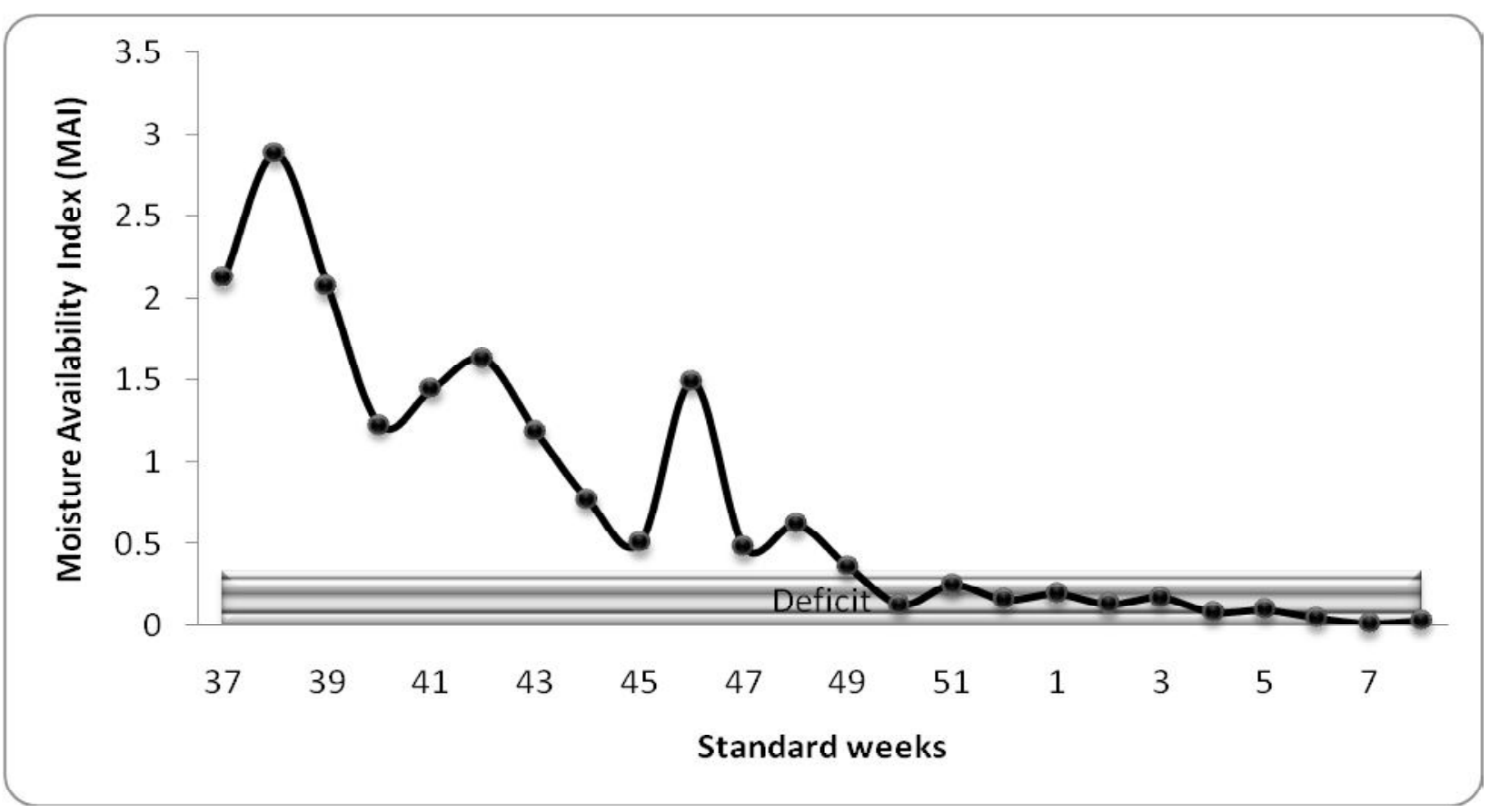

Fig 1: Moisture availability index (MAI) for cotton crop in Annur block

Table 2 : Results of the crop water balance for rainfed cotton ( $37^{\text {th }}$ Standard Week to $8^{\text {th }}$ Standard Week)

\begin{tabular}{|c|c|c|c|c|c|c|c|}
\hline \multirow{2}{*}{$\begin{array}{l}\text { Pedon } \\
\text { No. }\end{array}$} & \multirow[t]{2}{*}{ Soil series } & \multirow{2}{*}{$\begin{array}{c}\text { AWHC } \\
\text { in control } \\
\text { section }(\mathrm{mm})\end{array}$} & \multirow{2}{*}{$\begin{array}{c}\text { Surplus } \\
\text { weeks }\end{array}$} & \multirow{2}{*}{$\begin{array}{l}\text { Deficit } \\
\text { weeks }\end{array}$} & \multicolumn{3}{|c|}{ Cumulative values } \\
\hline & & & & & $\begin{array}{c}\text { Surplus } \\
(\mathrm{mm})\end{array}$ & $\begin{array}{c}\text { Deficit } \\
\text { (mm) }\end{array}$ & WRSI \\
\hline 1. & Vadakkalur & 36.3 & $41-43$ & $5-8$ & 11.5 & 57.8 & 88.4 \\
\hline 2. & Annur Mettupalayam & 28.1 & $39-48$ & $5-8$ & 14.3 & 61.9 & 87.5 \\
\hline 3. & Ambodi & 26.5 & $39-47$ & $4-8$ & 4.9 & 62.8 & 87.4 \\
\hline 4. & Odderpalayam & 26.9 & $39-47$ & $4-8$ & 3.5 & 62.6 & 87.4 \\
\hline 5. & Kariampalayam & 82.1 & - & $6-8$ & - & 34.9 & 93.0 \\
\hline 6. & Allapalayam & 28.6 & - & $5-8$ & - & 61.7 & 87.6 \\
\hline \multirow[t]{2}{*}{7.} & Kuppipalayam & 28.1 & $39-48$ & $5-8$ & 14.3 & 61.9 & 87.5 \\
\hline & Mean & 36.7 & - & - & 9.7 & 57.7 & 88.4 \\
\hline
\end{tabular}

weeks and overall WRSI for cotton showed that there was less rainfall from $50^{\text {th }}$ standard week to $8^{\text {th }}$ standard week $(1.9$ to $3.6 \mathrm{~mm})$ (Table 2). The rainfall amount from $37^{\text {th }}$ to $49^{\text {th }}$ standard weeks was good and it was more than the crop water requirement. So a cumulative surplus amount of water was found which ranged from $3.5 \mathrm{~mm}$ to $14.3 \mathrm{~mm}$. This surplus water varied mainly due to soil texture and depth of soil. The water deficit was found high in Ambodi $(62.8 \mathrm{~mm})$ and Odderpalayam $(62.6 \mathrm{~mm})$ soils because of poor available water holding capacity ( 26.5 and $26.9 \mathrm{~mm}$, respectively)in the control section.In deep soils having higher available water holding capacity (AWHC) maintained the WRSI at 100 per cent up to $4^{\text {th }}$ standard week. The water deficit occurred only at $5^{\text {th }}, 6^{\text {th }}, 7^{\text {th }}$ and $8^{\text {th }}$ standard weeks. For example the very deep soils of Kariampalayam series has got very low water deficit ( $34.9 \mathrm{~mm}$ ), high WRSI (93) and there was no surplus water due to high available water holding capacity in the control section $(82.1 \mathrm{~mm})$. The WRSI for the soil types revealed that around 88.4 per cent of the total water requirement by the crop was satisfied till harvest. The overall comparison revealed that the shallow soil along with sandy loam texture recorded water deficits and water requirement satisfaction index (WRSI) was found to be low (87.4). From the WRSI, it was evident that the terminal stage of the cotton crop met water stress which coincide the harvesting stage. Cultivation short duration crops along with moisture conservation practices will avoid the yield loss due to water stress. The surplus water observed also 
has to be conserved in soil control section to meet out the crop requirement in lateral stage. The availability of sufficient water at critical stages enhanced the cotton production in the study area.

\section{REFERENCES}

Allen, R.G., Pereira, L.S., Raes, D., and Smith, S., (1998). Crop Evapotranspiration-Guidelines for computing crop water requirements-FAO irrigation and Drainage Paper no.56. Rome Italy: Food and Agriculture Organization of the United Nations (FAO).

Frere, M., and Popov, G.F., (1979). Agrometerological crop monitoring and forecasting. Plant Production and Protection Paper, FAO, Rome, Italy.

Gabriel Senay, B., and James, Verdin., (2002). Evaluating the performance of a crop waterbalance model in estimating regional crop production. Pecoral and land satellite information IV, ISPRS commission. In: Proceedings of FIEOS conference.

Gupta, R.P., and Dakshinamurthi, C., (1980). Procedures for physical analysis of soils and collection of agrometeorolocical data. Division of Agricultural physics, Indian Agricultural Research Institute, New Delhi.

Hillel, Daniel., (1982). Introduction to soil physics: New York, Academic Press, $364 \mathrm{p}$.

Jackson, M.L., (1973). Soil chemical analysis. Oxford IBH Publishing Co., Bombay.

Oweis, T., and Hachum, A., (2009). Supplemental irrigation for improved rainfed agriculture in WANA region. In: Wani, S.P. Rockström, J. Oweis, T. eds. Rainfed agriculture: unlocking the potential. Comprehensive Assessment of Water Management in Agriculture Series 7. Wallingford, UK: CABI; Patancheru, Andhra Pradesh, India: International Crops Research Institute for the Semi-Arid Tropics (ICRISAT); Colombo, Sri Lanka: International Water Management Institute (IWMI). pp182-196.

Piper, C.S., (1966). Soil and plant analysis. Inter Science publication. Inc. New York.

Richard, Shine., and Gregory, P., (2008). Adapting to the unpredictable: reproductive biology of vertebrates in the Australian wet-dry tropics Brown. Phil. Trans. R. Soc. B. 363,363-373 doi:10.1098/rstb.2007.2144

Richardson, C.W., and Ritchie, J.T., (1973). Soil water balance of rainfall watersheds. Trans. ASAE., 16:2-77.

Rockstrom, J., (2000). Water resources management in small holder farms in Eastern and southern Africa. An overview. Physics Chemistry Earth, 25(3):278-288.

Sarkar, R.P., and Biswas, B.C., (1988). Anew approach to agro climatic classification to find out croppotential.Mausam, 39(4):343-358.

Schaible, G.D., andAillery, M.P., (2012). Water Conservation in Irrigated Agriculture: Trends and Challenges in the Face of Emerging Demands, Economic Information Bulletin:99, ERS-USDA, at: http://www.ers.usda.gov/ media/884158/eib99.pdf

Sehgal, J., and Mandal, D.K., (1993). Soil moisture regimes in India. Technical Bulletin. NBSS Publication, 43. National Bureau of Soil Survey and Land Use Planning, Nagpur.

Senay, G.B., Leake, S., Nagler, P.L., Artan, G., Dickinson, J., Cordova, J.T., and Glenn, E.P., (2011). Estimating basin scale evapotranspiration (ET) by water balance and remote sensing methods. Hydrol. Proces., 25 (6): 4037 -4049 .

Singh, K.B., (2005). Field evaluation of soil water balance model. J. Indian Soci. Soil Sci., 53(3): 288-295.

Soil Survey Staff., (2008) Keys to Soil Taxonomy, 11 th Edison. SCS, USDA, Washigton, DC.

Thakural, L.N., Kumar Sanjay., Singh Surjeet., Kumar Rakesh., Jain Sanjay, K., Thomas, T., and Mishra, S.K., (2009). Estimation of Water Balance Components in the Dhasan river basin. Water Energy Res. Digest, 19(3): 2-8.

Wright, J.L., (1982). New evapo-transpiration crop coefficiencies. J. Irrig Drain. Div., 108: 57-74.

Yamoah, Charles., Varvel Gary., Francis Charles and Waltman William., (1998). Weather and Management Impact on Crop Yield Variability in Rotations. Agronomy \& Horticulture- Faculty Publications. Paper 331. http:// digitalcommons.unl.edu/agronomyfacpub/331 